Tracking the Scholarship of Teaching and Learning

Malcolm Tight

Department of Educational Research, Lancaster University, Lancaster LA1 $4 Y L$, UK

m.tight@lancaster.ac.uk 


\title{
Tracking the Scholarship of Teaching and Learning
}

\begin{abstract}
The scholarship of teaching and learning has become an increasingly popular theme for discussion, research and practice in higher education over the last three decades. In essence, this idea recognizes the importance of taking a critical and research-based approach to teaching and learning, and, in doing so, attempts to elevate the status of the teaching role in comparison to research. This article explores the derivation and development of the scholarship of teaching and learning, and considers its application and critique, through a systematic review of the academic literature. It concludes that, while the scholarship of teaching and learning has been influential in terms of thinking, practice and policy - particularly at the level of the individual, course or department - it has not led to the development of new or innovative lines of research. While it might be argued that this was not its intention, it has limited its impact.
\end{abstract}




\section{Introduction}

Higher education is an inter-disciplinary field for research (Brennan and Teichler 2008, Kehm and Musselin 2013, Tight 2012). With only a limited number of academic and other researchers devoting themselves full-time and long-term to researching higher education, most of those researching this field come from and remain based in other disciplines, departments or institutions, and their contributions are usually part-time and/or shortterm.

While this means that higher education researchers are highly dispersed, it also has a more positive aspect, as a diverse range of methodologies, theoretical frameworks, research designs and, in the broadest sense, ideas are applied to researching higher education. While many of these are introduced from other disciplines - by researchers with a background or interest in those disciplines - other methodologies, theories and designs are also developed within higher education research itself (Tight 2012, 2013, 2014a).

This article forms part of a larger research project, which is tracing the origins, spread and development of particular theories, methodologies, research designs and ideas of influence within higher education research (see also Tight 2014b, 2014c, 2015a, 2015b, 2015c, 2016a, 2016b). In addition to charting where they come from, how popular they are and how they change over time, the project is considering why and how these theories, methodologies, research designs and ideas are being used, their relation to other frameworks, and the critiques of them that have been advanced.

In this article, the focus is on the scholarship of teaching and learning, used within higher education research (and higher education more generally) for articulating the idea that greater critical attention needs to be paid to teaching and learning. The scholarship of teaching and learning has developed over the last three decades, and, in that time, it has proved to be both resilient and popular internationally.

The aim of the article is to provide a comprehensive account of how the scholarship of teaching and learning has developed and been applied. It does this by carrying out a systematic review (Jesson, Matheson and Lacey 2011, Torgerson 2003) of the literature on the topic that has been published in the English language. Relevant articles, books and chapters were identified using databases and search engines, such as Google Scholar and Scopus; copies were then obtained for scrutiny and analysis.

The remainder of the article is organized in four main sections. First, the origins of the idea are discussed, and its meaning is examined. Its application to higher education by researchers and practitioners is then reviewed. The issues and criticisms concerning it are considered. Finally, 
some conclusions are reached on the nature and achievements of the scholarship of teaching and learning.

\section{Origins and Meaning}

The scholarship of teaching and learning is a movement as much as an idea, and may be closely linked to discussion around the research/teaching nexus (i.e. the relationship between the research and teaching functions of higher education: Tight 2016b). It developed partly as a reaction to quantitative studies, chiefly American, which found no strong relationship between research and teaching (e.g. Feldman 1987, Hattie and Marsh 1996). This had policy consequences, with an increasing de-coupling of funding for and oversight of research and teaching. In such an environment, the fear was that the research function would assume increasing prominence, particularly in the leading universities, resulting in a perceived need to re-emphasize the importance of teaching and learning.

While this is, of course, a long-standing debate, it was given a renewed edge in the last decades of the twentieth century through the development of the notion of, initially, the scholarship of teaching. The founding father of this movement was an American scholar, Boyer (1990; see also Boyer Commission on Educating Undergraduates in the Research University 1998, Rice 1991), whose starting position was that:

the most important obligation now confronting the nation's colleges and universities is to break out of the tired old teaching versus research debate and define, in more creative ways, what it means to be a scholar. It's time to recognize the full range of faculty talent and the great diversity of functions higher education must perform. (p. xii)

Boyer went on to identify four forms of scholarship - the scholarship of discovery (i.e. research as commonly understood), the scholarship of integration (i.e. synthesis, often inter-disciplinary in nature, of which this article is an example), the scholarship of application (i.e. applied research) and the scholarship of teaching (i.e. involving pedagogical learning and research) - each of which he saw as crucial to the life of the university.

Since Boyer's report was published, the scholarship of teaching - typically now broadened out as the scholarship of teaching and learning, recognising explicitly the importance of students as well as teachers (Boshier and Huang 2008) - has taken on a life of its own. This was helped, in the USA, by the funding available through the Carnegie Academy for the Scholarship of Teaching and Learning (Huber 2010). Numerous authored and edited books have been published by Boyer's coworkers at the Carnegie Foundation for the Advancement of Teaching and others (e.g. Glassick, Huber and Maeroff 1997, Gurung and Wilson 2013, 
Huber and Morreale 2002, Hutchings, Huber and Ciccone 2011, Kreber 2001, McKinney 2013, Murray 2008).

There is an international society (the International Society for the Scholarship of Teaching and Learning, founded in 2004), which organises an annual conference. The first specialist journal, the Journal of Scholarship of Teaching and Learning, started operations in 2001. It was followed by the International Journal for the Scholarship of Teaching and Learning in 2007, and a range of other national (e.g. the Canadian Journal for the Scholarship of Teaching and Learning, founded in 2010) or disciplinary (e.g. Scholarship of Teaching and Learning in Psychology, founded in 2014) journals focused on the topic. A number of other journals - including Assessment and Evaluation in Higher Education, Higher Education Research and Development and Teaching of Psychology - have published special issues on the topic.

So what is the scholarship of teaching and learning? Not surprisingly, there are different interpretations, and these have also developed over time (Kreber 2002a, 2002b, Fanghanel et al 2015). Thus, Kreber and Cranton (2000) identify three successive perspectives on what was then known as the scholarship of teaching: one valuing research on teaching and learning, a second emphasizing excellence in teaching, and a third involving the application of educational theory and research to practice.

A relatively early definition, incorporating at least two of these perspectives, is offered by two of Boyer's co-workers, Hutchings and Shulman:

A scholarship of teaching is not synonymous with excellent teaching. It requires a kind of "going meta", in which faculty [i.e. academic teachers] frame and systematically investigate questions related to student learning - the conditions under which it occurs, what it looks like, how to deepen it, and so forth - and do so with an eye not only to improving their own classroom but to advancing practice beyond it. (1999, p. 13)

Over a decade later, Hutchings and two co-authors came up with a more extended account:

The scholarship of teaching and learning encompasses a broad set of practices that engage teachers in looking closely and critically at student learning for the purpose of improving their own courses and programs. It is perhaps best understood as an approach that marries scholarly inquiry to any of the intellectual tasks that comprise the work of teaching - designing a course, facilitating classroom activities, trying out new pedagogical ideas, advising, writing student learning outcomes, evaluating programs. When activities like these are undertaken with serious questions about student learning in mind, one enters the territory of the scholarship of teaching and learning. (Hutchings, Huber and Ciccone 2011, p. 7) 
The key elements appear to remain much the same: questioning, criticality, adopting what we might call a 'researcherly' attitude towards teaching and learning practice.

Writing at the turn of the century, Trigwell and three other Australian coauthors identified a series of dimensions which could be used to judge the degree of engagement in the scholarship of teaching and learning:

(a) the extent to which they engage with the scholarly contributions of others, including the literature of teaching and learning of a general nature, and particularly that in their discipline;

(b) the focus of their reflection on their own teaching practice and the learning of students within the context of their own discipline: whether it is unfocused, or whether it is asking what do I need to know and how do I find out;

(c) the quality of the communication and dissemination of aspects of practice and theoretical ideas about teaching and learning in general, and teaching and learning within their discipline; and

(d) their conceptions of teaching and learning: whether the focus of their activities is on student learning and teaching or mainly on teaching. (Trigwell et al 2000, p. 163)

Four years later, writing with another Australian co-author, Trigwell emphasized the role of transparency and public scrutiny in making teaching and learning a scholarly process:

We see scholarship as being about making scholarly processes transparent and publicly available for peer scrutiny... We see teaching as a scholarly process aimed at making learning possible. It, therefore, follows that we see the scholarship of teaching as about making transparent, for public scrutiny, how learning has been made possible. (Trigwell and Shale 2004, p. 525)

Finally, as it would be possible to multiply quotations on the meaning of the scholarship of teaching and learning almost indefinitely, here is the view of one English academic:

Developing the scholarship of teaching is more than striving to be an excellent teacher or being scholarly. Whereas striving for excellence involves a high level of proficiency in stimulating students and fostering their learning in a variety of appropriate ways, a scholarly approach to teaching entails being familiar with the latest ideas in one's subject and also being informed by current ideas for teaching that subject. A scholarly approach also involves evaluating and reflecting on one's teaching practice and the student learning which follows. The scholarship of teaching shares these 
characteristics of excellent and scholarly teaching, but, in addition, involves communicating and disseminating about the teaching and learning practices of one's subject. It also entails investigating questions related to how students learn within a discipline. (Healey 2000, p. 172)

While there are undeniably differences in emphasis on display in these characterizations of the scholarship of teaching and learning, they are recognisably describing the same phenomena and several key components are evident throughout. Thus, the scholarship of teaching and learning was conceived as involving being an informed, questioning, reflecting, critical and inquiring teacher, whose focus is on the improvement of their teaching so as to improve their students' learning, and on sharing their practices widely with others so as to advance the status and practice of teaching and learning in their discipline and in higher education in general.

\section{Application and Practice}

The number of academic publications focusing on the scholarship of teaching and learning has increased significantly over the last three decades, as illustrated by Table 1 . This records the numbers of 'articles' (this term includes books, reports and other forms of publications as well as journal articles) identified in two popular databases, Scopus and Google Scholar, with the words 'scholarship of teaching' in their titles, abstracts, keywords or anywhere in the article (search carried out on $31 / 8 / 17)$. The term 'scholarship of teaching' was used rather than the more contemporary 'scholarship of teaching and learning' because the former search would also identify examples of the latter.

\section{[Table 1 here]}

As the table shows, Scopus and Google Scholar have different coverages, with the latter recording rather more articles than the former. Before 1990 there were only a handful of articles published with 'scholarship of teaching' in their titles or elsewhere, and they did not use that exact phrase: rather they were focused on some other aspect of the relationship between teaching and scholarship. For example, taking two very early articles, one (Milne 1911) was about 'The Teaching of Limits and Convergence to Scholarship Candidates', while another (Payne 1918) concerned 'Scholarship and Success in Teaching'.

From 1990 onwards, following the publication of the Boyer Report, several articles were published each year with a specific focus (as evidenced through their inclusion of the term in their titles) on the scholarship of teaching (and learning), as this is understood today. This figure rose to over 50 a year, taking the Google Scholar data, from 2007 onwards, with a peak to date of 72 articles published in 2012. This growth is, of course, a function not only of the increasing interest in the topic, but also of the 
increase in the number of journals and other outlets interested in publishing articles on the topic.

If the search is extended beyond article titles, many more publications are, of course, identified. Thus, a Scopus search for 'scholarship of teaching' in article titles, abstracts or keywords finds 335 articles published in 2016 alone (or 308 articles with the term in the abstract or keywords, if the 27 with it in their titles are excluded). Even more extensively, a Google Scholar search for items with the term mentioned anywhere in the article identifies around 4240 articles in the same year. Clearly, while articles with the term in their titles will likely be focused on the topic, and those with it in their abstract or keywords will probably give it some serious attention, the great majority with it anywhere in the article will only mention it in passing.

Significantly, research and writing on this topic is popular both in North America, where the term originated, and in the rest of the world. The more common pattern is for North America and the rest of the world to have different foci of interest, or at least to use different labels for the same focus (see Shahjahan and Kezar 2013; Tight 2014d). The topic has also been the subject of previous literature reviews, notably by Fanghanel et al (2015).

Critical academic writing and research on the scholarship of teaching and learning is now, therefore, an established feature of higher education research. While perhaps not truly global, this interest is particularly strong - naturally enough, given that the review focused on English language outputs - across the English-speaking world. Thus, articles have been published by authors based in Australia (e.g. Bennett et al 2016, Brew and Ginns 2008, Greaves 2015, Rowland and Myatt 2014), Canada (Boshier 2009, Simmons and Poole 2016), Ireland (O'Sullivan 2011), Malaysia (Harland, Hussain and Bakar 2014), New Zealand (Haigh, Gossman and Jiao 2011), Singapore (Geertsema 2016), South Africa (Leibowitz and Bozalek 2016, Mtawa, Fongwa and Wangenge-Ouma 2016), Sweden (Lindberg-Sand and Sonesson 2008, Martensson, Roxa and Olsson 2011), Trinidad and Tobago (Blair 2014), the United Kingdom (Craig 2014, Healey 2000) and the United States (e.g. Atkinson 2001, Burns 2017, Cottrell and Jones 2003, O'Meara 2003, Willingham-McLain 2015).

It is also notable that the interest in the scholarship of teaching and learning is genuinely cross-disciplinary (Huber and Morreale 2002). Thus, the research for this article identified examples of writing from academics in accounting (Lucas 2011), communication (McCroskey, Richmond and McCroskey 2002), dentistry (Lanning et al 2014), economics (Horspool and Lange 2012), education (Mitchell and Mitchell 2015, Pelliccione and Raison 2009), engineering (Kahn et al 2013, Nilsson 2013), geography (Healey 2003), history (Booth 2004, Pace 2004), hospitality (Deale 2010a, 2010b, La Lopa 2013), law (Greaves 2015), librarianship (Mitchell 
and Mitchell 2015), management (Adcroft and Lockwood 2010, Frost and Fukami 1997), mathematics (Bennett and Dewar 2012), nursing (Oermann 2014), occupational therapy (Hammel et al 2015), pharmacy (Peeters, Beltyukova and Martin 2013, Tofade, Abate and Fu 2014), philosophy (Riordan 2008), political science (Craig 2014, Hamann, Pollock and Wilson 2009, Trepanier 2017), psychology (Gurung et al 2008, Najdowski et al 2015), science (Rowland and Myatt 2014), social work (Grise-Owens, Owens and Miller 2016, Wehbi 2009), sociology (Atkinson 2001, Chin 2002, Lucal et al 2003, Paino et al 2012), textiles (Meyer and Kadolph 2005) and theology (Gravett 2016, Killen and Gallagher 2013).

This list could undoubtedly be extended. As it stands, it encompasses examples from health care, the arts and humanities, the sciences, engineering and the social sciences, as well as many professional disciplines. It would be reasonable to claim, therefore, that there has been at least some interest shown in the scholarship of teaching and learning across the disciplinary spectrum. In the United States, this interest has also been charted in specifically Christian institutions and journals (Smith, Um and Beversluis 2014).

Not surprisingly, a major concern of this literature is with 'how to do' the scholarship of teaching and learning (Fanghanel 2013). The suggestions made have included through academic development (Elton 2009, Hubball and Burt 2006, Roxa, Olsson and Martensson 2008), action learning (Albers 2008), collaborative scholarship (Weaver et al 2013), collaborative self-study (Louie et al 2003), design-based research (Sharma and McShane 2008), e-portfolios (Pelliccione and Raison 2009), e-teaching/learning (Benson and Brack 2009), expert teachers (Kreber 2003, Yair 2008), institutional research (Shreeve 2011), international writing groups (Marquis, Healey and Vine 2016), lesson study (Wood and Cajkler 2017), peer partnership (Barnard et al 2011), practice research (Hatch 2009), reflection (Cranton 2011, Kreber 2005, Nilsson 2013), reward (Roxa, Olsson and Martensson 2008), using theory (Hutchings and Huber 2008) and through shared practice (Kahn et al 2013). Others (e.g. Bartsch 2013a, 2013b; Kanuka 2011) have focused on how to research the scholarship of teaching and learning.

In practice, of course, a range of these techniques - and doubtless others - for 'doing' the scholarship of teaching and learning might well be employed. After all, one characteristic that they all share is being relatively innovative and contemporary good practice. They are some distance away from the more conventional practices of lectures, laboratory exercises, seminars and group tutorials, and thus require more thought and attention on the part of those academics seeking to implement them.

While most such analyses have - naturally enough, given the intended focus (at least originally) of the scholarship of teaching and learning on one's own teaching and one's own students' learning - operated at, or 
been focused on, the individual, course, department or discipline level, some have considered how the scholarship of teaching and learning might be best implemented at an institutional level:

The UKZN [University of KwaZulu-Natal] case provides empirical evidence that SoTL [ the scholarship of teaching and learning] can be grown and institutionalised. But for this to happen, a particular conception and approach to SoTL is needed and has relevance for institutionalising SoTL at a higher education system level... an organic approach offers a means for SoTL to be grown over time and when advanced, both strategically and structurally, it can become infused into the fabric of the institution. However, for this to happen, SoTL is best conceptualised as a multidimensional construct... The structure is the means by which a university can deploy the key dimensions of SoTL to facilitate institution-wide strategies and through which it can be generative of innovation and new initiatives. But the deployment of SoTL at an institutional level requires that its definition and meaning remain open and inclusive of the multiple aspects of T\&L [teaching and learning] research, practice, reflection and evaluation. (Vithal 2016, p. 13)

The claims made by proponents about the scholarship of teaching and learning can be quite far reaching. For example:

Using a transformative learning and critical theory lens to view the Scholarship of Teaching and Learning takes us to an emancipatory Scholarship of Teaching and Learning in which the assumptions, beliefs, norms and values of the discipline, the institution, the community and the state are directly and critically questioned. Such an approach has the potential to yield a deep shift in perspective on teaching and learning at both an individual level and a social level. (Cranton 2011, p. 85)

Another enthusiast, Kreber $(2013,2015)$, takes the discussion further in arguing that the scholarship of teaching and learning is not just an evidence-based but a virtues-based practice. She views this scholarship as being supported by 'the intellectual virtues of 'episteme' (theoretical knowledge), 'techne' (productive knowledge) and 'phronesis' (practical knowledge)' (2015, p. 568), with phronesis adopting a critical mediating function, enabling the 'proper development and enactment of moral virtues, especially truthfulness, justice and courage, without which the standards associated with scholarship could not be upheld' (ibid). She also views the evidence-based aspect of the scholarship of teaching and learning as incorporating two types of evidence: 'evidence of the internal ethical consistency between our strategies and desired ends and evidence of the effectiveness of these strategies in achieving these ends' (2015, p. 578). 
Leibowitz and Bozalek (2016), writing in the South African context, similarly link the scholarship of teaching and learning with a social justice approach. This would involve:

institutional arrangements which attend to the distribution of material as well as cultural resources amongst academics, and which attend to participatory process and a sense of inclusion and respect within research processes. Collaboration across institutional, disciplinary, national boundaries are necessary [sic], provided that attention is paid to the opportunities for participatory parity, and where relevant, to opportunities for destabilisation and discomfort. (p. 119)

Ultimately, however, the primary and most immediate reason for engaging in the scholarship of teaching and learning remains, of course, the desire to improve student learning and the student experience more generally. In this context, therefore, it is reassuring that there is some evidence that this actually occurs (Horspool and Lange 2012, Trigwell 2013). For example, an Australian study was able to conclude that:

we have shown that there is a significant relationship, at the faculty [i.e. individual academic] level, between engaging in the scholarship of teaching and learning, and changes in students' course experiences. In particular, we found that differences in faculty performances over three years (2002-2004) on the Scholarship Index were reliably associated with changes in student perceptions of Good Teaching, Appropriate Assessment, and Generic Skills development, between 2001 and 2005. (Brew and Ginns 2008, p. 543)

Set against these expansive and positive views of the practice of the scholarship of teaching and learning, however, there are also less positive accounts, particularly regarding the (relative) lack of rewards for those engaging in such scholarship when compared with conventional research (Chalmers 2011, Mathison 2015, O'Meara 2005, Vardi and Quin 2011, Willingham-McLain 2015). Thus, in the American context, Henderson and Buchanan note:

the relative decline in participation in the scholarship of teaching and learning at the doctoral universities suggests that pedagogical efforts do not fit well with their reward systems and missions. At the research university, participation in the scholarship of teaching and learning is in competition with writing grants and articles on cutting-edge research. (2007, pp. 536-537)

Similarly, in the UK, the exclusion of research into teaching and learning within one's own institution from the 'impact' element of the 2014 Research Excellence Framework (REF) exercise may have led to institutions omitting such research from other elements of REF, with consequences for both individuals' careers and future research priorities. 
Much of the drive to engage with the scholarship of teaching and learning continues to rest, therefore, with the individual academic and their motivation.

\section{Issues and Critique}

Not surprisingly, the Scholarship of Teaching and Learning (now frequently abbreviated as SoTL, an unfortunate acronym, which - to me at least - suggests inebriation), having established itself as an idea and/or a movement, has been subject to both critiques and responses to those critiques. Here, for example, is one proponent identifying a number of issues or 'impediments':

Each impediment makes SoTL a hard sell, particularly in researchintensive universities. Taken together, they constitute a formidable problem for those wanting to counter the marginalization of SoTL. First, there is a persistent tendency to use scholarship of teaching as a synonym for other activities. Second, Boyer's definition was conceptually confused. Third, it is difficult to operationalize. Some advocates aggregate SoTL elements and portray them as overlapping and interacting. Others disaggregate them and try to operationalize (and derive indicators) for each one separately. Fourth, much discourse concerning SoTL is anti-intellectual and located in a narrow neoliberalism. Fifth, there is an uncritical and almost quaint reliance on peer review as the mechanism to detect scholarship. (Boshier 2009, pp. 12-13)

In an earlier article, Boshier and one of his colleagues (Boshier and Huang 2008) went further in arguing that the scholarship of teaching and learning is marginalised in most institutions of higher education, not just the research-intensive universities, and that part of the problem is the subsidiary position that learning takes in relation to teaching. They argued that there is much to learn from adult and lifelong learning, and concluded that:

If SoTL is to survive, it needs regular doses of adult education and learning has to move upstairs. Bringing learning out of the basement does not mean throwing teaching onto the street. Survival of SoTL depends on having learning and teaching live together. They need an equilibrious relationship founded on mutual respect and recognition of the fact not all teaching involves learning. Important forms of learning occur beyond the gaze of teachers. Committed teachers need to back off to make way for learning. (p. 654)

To support this drive, they also suggest a change in name to the scholarship of learning and teaching. 
It is relatively easy to provide an illustration of how the scholarship of teaching and learning can seem to be so diffuse an idea as to add little to what already exists, and continues to exist, in this area of scholarship and research. We may, for example, look at the output in 2016 (the last full year available at the time of writing) of two journals that are explicitly focused on the topic, the Journal of the Scholarship of Teaching and Learning and the International Journal for the Scholarship of Teaching and Learning. The former published 24 articles in four issues during the year, while the latter produced 18 articles in two issues, giving a sample of 42 articles in all for examination and analysis.

Tellingly, only two of these articles (Manarin and Abrahamson 2016, Walls 2016), one from each of the journals examined, explicitly discussed the scholarship of teaching and learning. Manarin and Abrahamson considered the scholarship of teaching and learning as a form of 'troublesome knowledge', using survey and interview data with academics to illustrate their argument. Walls took a very particular perspective, examining how Bronfenbrenner's bioecological model of human development might be applied to the literature.

A further two articles made some limited reference to the literature on the scholarship of teaching and learning. The other 38 (out of 42) articles made no direct mention of the scholarship of teaching and learning. Instead they analysed particular pedagogical innovations - such as civic engagement, classroom design, critical thinking, cross-cultural pedagogies, diversity training, flipped classrooms, mind mapping, strategic reading, student motivation and uncertainty management - all of which might be accommodated within the scholarship of teaching and learning, but which could just as well have been published in any number of other higher education journals.

Incidentally, 37 out of the 42 articles were authored by academics based in the USA, with 2.5 authored by academics based in Canada, despite the inclusion of 'international' in one of the journals' titles. It may be, of course, that these journals' output in 2016 was atypical, but a scroll through back issues suggests otherwise.

One might conclude from this analysis, therefore, that, in practice, the scholarship of teaching and learning had little to add - other than, perhaps, a useful slogan - to existing and ongoing research on teaching and learning in higher education. There is clearly confusion and overlap between the scholarship of teaching and learning and, on the one hand, pedagogical research, and, on the other, higher education research in general. The initial focus of the scholarship of teaching and learning on one's own teaching and one's own students' learning - from which there has been, in any case, some slippage - may not be sufficient to distinguish it from related forms of research.

These conclusions may be complemented by a number of discipline-based surveys of the state of the scholarship of teaching and learning. Thus, 
Gurung et al (2008) report on the findings of an American survey of psychology departments:

despite our optimistic expectations, the survey respondents failed to report a prevailing sentiment of support for the "systematic, literature-based inquiry into processes and outcomes involved in teaching and learning" either among members of psychology departments or among the institutions that house them. (p. 257)

Hamann, Pollock and Wilson (2009) took a different approach, analysing the articles published in three US-based political science journals that focused on the scholarship of teaching and learning. They found that such articles were disproportionately authored by women and/or junior faculty, which could be interpreted positively - as they do - as indicating a healthy future for research in this area, or negatively as suggesting it was of less interest and importance to senior or established members of politics departments.

In a similar study, Paino et al (2012) looked at the articles published in another US-based journal, Teaching Sociology, over the 2000-2009 period. While they found an increase in the volume of relevant research being published in that journal, and an increasing sophistication in the approaches taken, they noted that relatively little of this research was externally funded and questioned 'just how institutionalized and accepted SoTL has really become' (p. 103).

In another American study, Henderson and Buchanan (2007) examined who was being published in a range of pedagogical and research-oriented journals across the disciplines for the 1997-2004 period. They also examined editorial board membership. Their main conclusion was that research and publishing on the scholarship of teaching and learning had become 'a special niche for faculty at comprehensive universities' ( $p$. 523); i.e. universities that were not research-intensive.

Moving away from the USA, a New Zealand study (Haigh, Gossman and Jiao 2011) undertook a stock-take of the scholarship of teaching and learning in three universities. Their findings, while suggestive of growth, also revealed that there was a long way to go:

The data gathered confirms that much SoTL-related activity is occurring and other sources of data suggest that this is applicable for all New Zealand universities. Activities mainly originate from, and represent part of the work of, the central teaching development services within each university... Confirmation that SoTL has a significant presence within New Zealand universities is evident in SoTL publications. While the data indicated quite variable publication patterns between the three universities during the period 2000 to $2005 \ldots$ the proportion of SoTL publications to research publications overall is relatively low for this period (3.6\%). (p. 14) 
In an Australian context, Bennett et al (2016) also argue for the pivotal role of academic development staff in maintaining and developing the scholarship of teaching and learning. They use the metaphor of the chimaera, a three-headed monster, to explore their developing academic identities:

Naming and claiming the Chimaera identity-metaphor for this diverse group of SoTL academics has been, perhaps, the most useful in the co-creation of a shared sense of academic validity and possibility... With many of us feeling misunderstood, isolated and alone in our experience of de-affiliated scholarship and teaching in the academic support centre, we turned to conversation to gain agency. (pp. 225-226)

Such a characterisation of SoTL practitioners, along with the evidence of its popularity amongst academic development and support staff, and the limited response elsewhere, does not bode well for the scholarship of teaching and learning, two and a half decades on.

\section{Discussion and Conclusions}

What, then, might we conclude from this systematic review of research and writing on the scholarship of teaching and learning over the last few decades?

First, we may return to the question of what the scholarship of teaching and learning is. In terms of the broader project on which I am engaged, it doesn't really qualify as a theory, a methodology or a research design, as a variety of all of these may be employed in pursuing the scholarship of teaching and learning. While criticality and reflexivity are undoubtedly central, these are hardly enough on their own to make the scholarship of teaching and learning a distinctive method.

I would, therefore, characterize the scholarship of teaching and learning as an idea and/or a movement, which is, reassuringly, what many of its proponents claim. It is an idea in that it encapsulates the notion that teaching and learning in higher education should be approached and practised in a scholarly fashion. It is a movement in that it provides a rallying call for all lecturers and tutors to take their teaching and their students' learning more seriously. As an academic movement it is evidenced and buttressed by the usual panoply of specialist journals, societies and conferences at disciplinary, national and international levels.

Second, there is something of an issue about the label(s) used for this idea and movement, though I would have to recognise that there is probably little that can be done about this now, given it has had over 25 years of use and recognition internationally. Yet, whether it is termed the scholarship of teaching, or of teaching and learning, or of learning and teaching (all of which are rather a mouthful) - or the, frankly, appalling 
abbreviations or acronyms of SoT, SoTL or SoLT are used - there is something both limiting and rather old-fashioned about the terminology.

Third, there is a dissonance between the founding focus of the movement on the research-intensive universities, in particular, and the, unsurprisingly, broader interest in and support for the idea in higher education institutions with a primary focus on teaching students. Aiming 'high' is both understandable and admirable, but the evidence suggests that there is much more mileage in targeting new, younger academics working in institutions and departments oriented towards teaching and learning.

Fourth, these three points of identity, label and focus draw attention to a further aspect of the development and application of the scholarship of teaching and learning. Namely, like many ideas that have been around for a while (cf. communities of practice, which morphed from being an analysis of how communities operate to a management tool in little more than a decade (Tight 2015c)), there has been some slippage in interpretation and practice. While the early advocates emphasized a focus on one's own teaching and one's own students' learning, later authors have applied the idea at departmental or institutional, and even national, levels.

Fifth, and finally, some assessment of the success or otherwise of the scholarship of teaching and learning is called for. In this respect, it is clear that much has been researched and published, and that an associated network of events and organizations has been established; though, at the same time, much more could, of course, be done.

An inherent problem with the scholarship of teaching and learning is that, despite the slippage in interpretation noted, most research remains (true to the original intention) small-scale, short-term and local in orientation. That is acceptable if the intention is simply to engage in individual scholarship - with all of the wheel re-invention that this will necessarily involve - but if the aim is to have a wider impact, some comparison and synthesis of findings is called for, and even, perhaps, coordinated, largerscale studies.

This is shown by the articles examined in this analysis. Over 100 of these are referenced, and, while these obviously do not include everything that has been published on the scholarship of teaching and learning during the last three decades, they do represent an extensive sample. Unsurprisingly, given my focus on the nature and development of the idea, over half of these articles are overviews or conceptual discussions of the scholarship of teaching and learning. The remainder include a significant empirical component, with the great majority of these being small-scale case studies. They describe, discuss and evaluate the practice of the scholarship of teaching and learning at the level of the individual, the course, the department or, occasionally, the institution. This is, of 
course, typical of research into teaching and learning, course design and the student experience in general (Tight 2012).

Very few articles review data collected at the national level on the experience and practice of the scholarship of teaching and learning (e.g. Gurung et al 2008, Lanning et al 2014, Lindberg-Sand and Sonesson 2008, O'Meara 2005, Trigwell 2013). This suggests that, even where the scholarship of teaching and learning has been supported through national policy or funding, either directly (as in the USA: Huber 2010) or indirectly (as in Australia, Sweden and the UK: Chalmers 2011, Shreeve 2011), the achievements have been limited.

Small-scale research, particularly at the individual level, seldom has much impact beyond the individual or individuals concerned. This tendency is not helped when the resourcing available to support such research is insufficient, or the commitment is only short-term. Whatever impact the research has had is then likely to be quickly forgotten. Further problems are likely to ensue if the aims of the scholarship of teaching and learning clash with academics' values or other roles, forcing a choice.

We may also, though, question whether a lot of this activity - under some other label or in the general guise of pedagogical research and academic development - would have taken place anyway. Added to this is the sense that the scholarship of teaching and learning is simply the current (and temporary) manifestation, and labelling, of an ongoing concern regarding the quality of teaching and learning in our universities and colleges. That is, of course, not a 'bad thing' in itself; indeed, it is normal practice. Yet it does suggest that, in 30, 40 or 50 years' time, the scholarship of teaching and research will be little more than a historical footnote, scarcely remembered by anyone. 


\section{References}

Adcroft, A, and Lockwood, A (2010) Enhancing the Scholarship of Teaching and Learning: an organic approach. Teaching in Higher Education, 15, 5, pp. 479-491.

Albers, C (2008) Improving Pedagogy through Action Learning and Scholarship of Teaching and Learning. Teaching Sociology, 36, 1, pp. 7986.

Atkinson, M (2001) The Scholarship of Teaching and Learning: reconceptualising scholarship and transforming the academy. Social Forces, 79, 4, pp. 1217-1230.

Barnard, A, Croft, W, Irons, R, Cuffe, N, Bandara, W, and Rowntree, P (2011) Peer Partnership to enhance Scholarship of Teaching: a case study. Higher Education Research and Development, 30, 4, pp. 435-448.

Bartsch, R (2013a) Designing SoTL Studies - Part 1: Validity. New Directions for Teaching and Learning, 136, pp. 17-33.

Bartsch, R (2013b) Designing SoTL Studies - Part 2: Practicality. New Directions for Teaching and Learning, 136, pp. 35-48.

Bennett, C, and Dewar, J (2012) An Overview of the Scholarship of Teaching and Learning in Mathematics. PRIMUS, 22, 6, pp. 458-473.

Bennett, R, Hobson, J, Jones, A, Martin-Lynch, P, Scutt, C, Strehlow, K, and Veitch, S (2016) Being Chimaera: a monstrous identity for SoTL academics. Higher Education Research and Development, 35, 2, pp. 217228.

Benson, R, and Brack, C (2009) Developing the Scholarship of Teaching: what is the role of e-teaching and learning? Teaching in Higher Education, 14, 1, pp. 71-80.

Blair, E (2014) Academic Development through the Contextualization of the Scholarship of Teaching and Learning: reflections drawn from the recent history of Trinidad and Tobago. International Journal for Academic Development, 19, 4, pp. 330-340.

Booth, A (2004) Rethinking the Scholarly: developing the scholarship of teaching in history. Arts and Humanities in Higher Education, 3, 3, pp. 247-66.

Boshier, R (2009) Why is the Scholarship of Teaching and Learning such a Hard Sell? Higher Education Research and Development, 28, 1, pp. 1-15.

Boshier, R, and Huang, Y (2008) In the House of Scholarship of Teaching and Learning (SoTL), Teaching Lives Upstairs and Learning in the Basement. Teaching in Higher Education, 13, 6, pp. 645-656. 
Boyer, E (1990) Scholarship Reconsidered: priorities of the professoriate. Princeton, NJ: Carnegie Foundation for the Advancement of Teaching.

Boyer Commission on Educating Undergraduates in the Research University (1998) Reinventing Undergraduate Education: a blueprint for America's research universities.

Brennan, J, and Teichler, U (2008) The Future of Higher Education and of Higher Education Research. Higher education looking forward: an introduction. Higher Education, 56, pp. 259-264.

Brew, A, and Ginns, P (2008) The Relationship between Engagement in the Scholarship of Teaching and Learning and Students' Course Experiences. Assessment and Evaluation in Higher Education, 33, 5, pp. 535-545.

Burns, K (2017) Community College Faculty as Pedagogical Innovators: how the scholarship of teaching and learning (SoTL) stimulates innovation in the classroom. Community College Journal of Research and Practice, 41, 3, pp. 153-167.

Chalmers, D (2011) Progress and Challenges to the Recognition and Reward of the Scholarship of Teaching in Higher Education. Higher Education Research and Development, 30, 1, pp. 25-38.

Chin, J (2002) Is there a Scholarship of Teaching and Learning in Teaching Sociology? A look at papers from 1984 to 1999. Teaching Sociology, 30, 1, pp. 53-62.

Cottrell, S, and Jones, E (2003) Researching the Scholarship of Teaching and Learning: an analysis of current curriculum practices. Innovative Higher Education, 27, 3, pp. 169-181.

Craig, J (2014) What Have We Been Writing About? Patterns and Trends in the Scholarship of Teaching and Learning in Political Science. Journal of Political Science Education, 10, 1, pp. 23-36.

Cranton, P (2011) A Transformative Perspective on the Scholarship of Teaching and Learning. Higher Education Research and Development, 30, 1 , pp. 75-86.

Deale, C (2010a) A Case Study of the Scholarship of Teaching and Learning in a Food Safety Class. Journal of Culinary Science and Technology, 8, 1, pp. 33-49.

Deale, C (2010b) What Teachers Learn from Students: focusing on the Use of Student Products and Qualitative Methods in the Scholarship of Teaching and Learning in Hospitality and Tourism. Journal Oof Teaching in Travel and Tourism, 10, 4, pp. 378-394.

Elton, L (2009) Continuing Professional Development in Higher Education: the role of the scholarship of teaching and learning. Arts and Humanities in Higher Education, 8, 3, pp. 247-258. 
Fanghanel, J (2013) Going Public with Pedagogical Inquiries: SoTL as a methodology for faculty professional development. Teaching and Learning Inquiry, 1, 1, pp. 59-70.

Fanghanel, J, McGowan, S, Parker, P, McConnell, C, Potter, J, Locke, W, and Healey, M (2015) Literature Review. Defining and supporting the Scholarship of Teaching and Learning (SoTL): a sector-wide study. York: Higher Education Academy.

Feldman, K (1987) Research Productivity and Scholarly Accomplishment of College Teachers as related to their Instructional Effectiveness: a review and exploration. Research in Higher Education, 26, 3, pp. 227298.

Frost, P, and Fukami, C (1997) Teaching Effectiveness in the Organizational Sciences: recognizing and enhancing the scholarship of teaching. Academy of Management Journal, 40, 6, pp. 1271-1281.

Geertsema, J (2016) Academic Development, SoTL and Educational Research. International Journal for Academic Development, 21, 2, pp. 122-134.

Glanville, I, and Houde, S (2004) The Scholarship of Teaching: implications for nursing faculty. Journal of Professional Nursing, 20, 1, pp. 7-14.

Glassick, C, Huber, M, and Maeroff, G (1997) Scholarship Assessed: evaluation of the professoriate. San Francisco, CA: Jossey-Bass.

Gravett, E (2016) The Scholarship of Teaching and Learning in Religious Studies. Journal of the American Academy of Religion, 84, 3, pp. 589616.

Greaves, K (2015) Is Scholarship of Teaching and Learning in Practical Legal Training a Professional Responsibility? The Law Teacher, 49, 1, pp. 22-38.

Grise-Owens, E, Owens, L, and Miller, J (2016) Conceptualizing the Scholarship of Teaching and Learning for Social Work Education. Journal of Social Work Education, 52, 1, pp. 6-17.

Gurung, R, Ansberg, P, Alexander, P, Lawrence, N, and Johnson, D (2008) The State of the Scholarship of Teaching and Learning in Psychology. Teaching of Psychology, 35, 4, pp. 249-261.

Gurung, R, and Wilson, J (eds) (2013) Doing the Scholarship of Teaching and Learning: measuring systematic changes to teaching and improvements in learning. Hoboken, NJ, John Wiley. New Directions for Teaching and Learning No. 136.

Haigh, N, Gossman, P, and Jiao, X (2011) Undertaking an Institutional 'Stock-take' of SoTL: New Zealand university case studies. Higher Education Research and Development, 30, 1, pp. 9-23. 
Hamann, K, Pollock, P, and Wilson, B (2009) Who SoTls where? Publishing the Scholarship of Teaching and Learning in Political Science. PS: Political Science and Politics, 42, 4, pp. 729-735.

Hammel, J, Magasi, S, Mirza, M, Fischer, H, Preissner, K, Peterson, E, and Suarez-Balcazar, Y (2015) A Scholarship of Practice Revisited: creating community-engaged occupational therapy practitioners, educators and scholars. Occupational Therapy in Health Care, 29, 4, pp. 352-369.

Harland, T, Hussain, R, and Bakar, A (2014) The Scholarship of Teaching and Learning: challenges for Malaysian Academics. Teaching in Higher Education, 19, 1, pp. 38-48.

Hatch, T (2009) The Scholarship of Teaching and Web-based Representations of Teaching in the United States: definitions, histories and new directions. Educational Action Research, 17, 1, pp. 63-78.

Hattie, J, and Marsh, H (1996) The Relationship between Teaching and Research: a meta-analysis. Review of Educational Research, 66, 4, pp. 507-542.

Healey, M (2000) Developing the Scholarship of Teaching in Higher Education: a discipline-based approach. Higher Education Research and Development, 19, 2, pp. 169-189.

Healey, M (2003) Promoting Lifelong Professional Development in Geography Education: international perspectives on developing the scholarship of teaching in higher education in the twenty-first century. The Professional Geographer, 55, 1, pp. 1-17.

Henderson, B, and Buchanan, H (2007) The Scholarship of Teaching and Learning: a special niche for faculty at comprehensive universities? Research in Higher Education, 48, 5, pp. 523-543.

Horspool, A, and Lange, C (2012) Applying the Scholarship of Teaching and Learning: student perceptions, behaviours and success online and face-to-face. Assessment and Evaluation in Higher Education, 37, 1, pp. 73-88.

Hubball, H, and Burt, H (2006) The Scholarship of Teaching and Learning: theory-practice integration in a faculty certificate program. Innovative Higher Education, 30, 5, pp. 327-344.

Huber, M (2010) Editorial: CASTL has concluded. Long live the scholarship of teaching and learning! Arts and Humanities in Higher Education, 9, 1, pp. 5-8.

Huber, M, and Morreale, S (eds) (2002) Disciplinary Styles in the Scholarship of Teaching and Learning: exploring common ground. Washington, DC: American Association for Higher Education and the Carnegie Foundation for the Advancement of Teaching. 
Hutchings, P, and Huber, M (2008) Placing Theory in the Scholarship of Teaching and Learning. Arts and Humanities in Higher Education, 7, 3, pp. 229-244.

Hutchings, P, Huber, M, and Ciccone, A (2011) The Scholarship of Teaching and Learning Reconsidered: institutional integration and impact. San Francisco, CA, Jossey-Bass.

Hutchings, P, and Shulman, L (1999) The Scholarship of Teaching: new elaborations, new developments. Change, 31, 5, pp. 10-15.

Jesson, J, Matheson, L, and Lacey, F (2011) Doing Your Literature Review: traditional and systematic techniques. London, Sage.

Kahn, P, Goodhew, P, Murphy, M, and Walsh, L (2013) The Scholarship of Teaching and Learning as Collaborative Working: a case study in shared practice and collective purpose. Higher Education Research and Development, 32, 6, pp. 901-914.

Kanuka, H (2011) Keeping the Scholarship in the Scholarship of Teaching and Learning. International Journal for the Scholarship of Teaching and Learning, 5, 1, article 3.

Kehm, B, and Musselin, C (eds) (2013) The Development of Higher Education research in Europe: 25 years of CHER. Rotterdam, Sense Publishers.

Killen, P, and Gallagher, E (2013) Sketching the Contours of the Scholarship of Teaching and Learning in Theology and Religion. Teaching Theology and Religion, 16, 2, pp. 107-124.

Kreber, C (ed) (2001) Scholarship Revisited: perspectives on the scholarship of teaching. San Francisco, CA: Jossey-Bass. New Directions for Teaching and Learning, Number 86.

Kreber, C (2002a) Controversy and Consensus on the Scholarship of Teaching. Studies in Higher Education, 27, 2, pp. 151-167.

Kreber, C (2002b) Teaching Excellence, Teaching Expertise and the Scholarship of Teaching. Innovative Higher Education, 27, 1, pp. 5-23.

Kreber, C (2003) The Scholarship of Teaching: a comparison of conceptions held by experts and regular academic staff. Higher Education, 46, pp. 93-121.

Kreber, C (2005) Reflection on Teaching and the Scholarship of Teaching: focus on science instructors. Higher Education, 50, pp. 323-359.

Kreber, C (2013) Empowering the Scholarship of Teaching: an Arendtian and critical perspective. Studies in Higher Education, 38, 6, pp. 857-869.

Kreber, C (2015) Reviving the Ancient Virtues in the Scholarship of Teaching, with a slight critical twist. Higher Education Research and Development, 34, 3, pp. 568-580. 
Kreber, C, and Cranton, P (2000) Exploring the Scholarship of Teaching. Journal of Higher Education, 71, 4, pp. 476-495.

La Lopa, J (2013) The Scholarship of Teaching. Journal of Culinary Science and Technology, 11, 2, pp. 183-202.

Lanning, S, McGregor, M, Crain, G, Van Ness, C, Keselyak, N, and Killip, J (2014) The Status of the Scholarship of Teaching and Learning in Dental Education. Journal of Dental Education, 78, 10, pp. 1353-1363.

Leibowitz, B, and Bozalek, V (2016) The Scholarship of Teaching and Learning from a Social Justice Perspective. Teaching in Higher Education, 21, 2, pp. 109-122.

Lindberg-Sand, A, and Sonesson, A (2008) Compulsory Higher Education Training in Sweden: development of a national standards framework based on the Scholarship of Teaching and Learning. Tertiary Education and Management, 14, 2, pp. 123-139.

Louie, B, Drevdahl, D, Purdy, J, and Stackman, R (2003) Advancing the Scholarship of Teaching through Collaborative Self-Study. Journal of Higher Education, 74, 2, pp. 150-171.

Lucal, B, Albers, C, Ballantine, J, Burmeister-May, J, Chin, J, Dettmer, S, and Larson, S (2003) Faculty Assessment and the Scholarship of Teaching and Learning: knowledge available/knowledge needed. Teaching Sociology, 31, 2, pp. 146-161.

Lucas, U (2011) Towards a 'Scholarship of Teaching and Learning': the individual and the communal journey. Accounting Education, 20, 3, pp. 239-243.

Manarin, K, and Abrahamson, E (2016) Troublesome Knowledge of SoTL. International Journal for the Scholarship of Teaching and Learning, 10, 2, article 2.

Marquis, E, Healey, M, and Vine, M (2016) Fostering Collaborative Teaching and Learning Scholarship through an International Writing Group Initiative. Higher Education Research and Development, 35, 3, pp. 531-544.

Martensson, K, Roxa, T, and Olsson, T (2011) Developing a Quality Culture through the Scholarship of Teaching and Learning. Higher Education Research and Development, 30, 1, pp. 51-62.

Mathison, K (2015) Effects of the Performance Management Context on Australian Academics' Engagement with the Scholarship of Teaching and Learning: a pilot study. Australian Educational Researcher, 42, pp. 97116.

McCroskey, L, Richmond, V, and McCroskey, J (2002) The Scholarship of Teaching and Learning: contributions from the discipline of communication. Communication Education, 51, 4, pp. 383-391. 
McKinney, K (ed) (2013) The Scholarship of Teaching and Learning in and across the Disciplines. Bloomington, IN, Indiana University Press.

Meyer, D, and Kadolph, S (2005) The Scholarship of Teaching and Learning in Textiles and Apparel. Clothing and Textiles Research Journal, 23,4 , pp. 209-215

Milne, W (1911) The Teaching of Limits and Convergence to Scholarship Candidates. Mathematical Gazette, 6, 96, pp. 79-84.

Mitchell, L, and Mitchell, E (2015) Using SoTL as a Lens to Reflect and Explore for Innovation in Education and Librarianship. Technical Services Quarterly, 32, 1, pp. 46-58.

Mtawa, N, Fongwa, S, and Wangenge-Ouma, G (2016) The Scholarship of University-Community Engagement: interrogating Boyer's model. International Journal of Educational Development, 49, pp. 126-133.

Murray, R (ed) (2008) The Scholarship of Teaching and Learning in Higher Education. Maidenhead, Open University Press.

Najdowski, C, Bottoms, B, Stevenson, M, and Veilleux, J (2015) A Historical Review and Resource Guide to the Scholarship of Teaching and Training in Psychology and Law and Forensic Psychology. Training and Education in Professional Psychology, 9, 3, pp. 217-228.

Nilsson, P (2013) Developing a Scholarship of Teaching in Engineering: supporting reflective practice through the use of a critical friend. Reflective Practice, 14, 2, pp. 196-208.

Oermann, M (2014) Defining and Assessing the Scholarship of Teaching in Nursing. Journal of Professional Nursing, 30, 5, pp. 370-375.

O'Meara, K (2005) Encouraging Multiple Forms of Scholarship in Faculty Reward Systems: does it make a difference? Research in Higher Education, 46, 5, pp. 479-510.

O'Sullivan, S (2011) Applying the Scholarship of Teaching and Learning in an Irish Context: mission impossible? Teaching Sociology, 39, 3, pp. 303319.

Pace, D (2004) The Amateur in the Operating Room: history and the scholarship of teaching and learning. American Historical Review, October, pp. 1171-1192.

Paino, M, Blankenship, C, Grauerholz, L, and Chin, J (2012) The Scholarship of Teaching and Learning in Teaching Sociology: 1973-2009. Teaching Sociology, 40, 2, pp. 93-106.

Payne, E (1918) Scholarship and Success in Teaching. Journal of Educational Psychology, 9, 4, pp. 217-219. 
Peeters, M, Beltyukova, A, and Martin, B (2013) Educational Testing and Validity of Conclusions in the Scholarship of Teaching and Learning. American Journal of Pharmaceutical Education, 77, 9, article 186.

Pelliccione, L and Raison, G (2009) Promoting the Scholarship of Teaching through Reflective e-Portfolios in Teacher Education. Journal of Education for Teaching, 35, 3, pp. 271-281.

Rice, E (1991) The New American Scholar: scholarship and the purposes of the university. Metropolitan Universities, 1, 4, pp. 7-18.

Riordan, T (2008) Disciplinary Expertise Revisited: the scholarship of teaching and learning philosophy. Arts and Humanities in Higher Education, 7, 3, pp. 262-275.

Rowland, S, and Myatt, P (2014) Getting Started in the Scholarship of Teaching and Learning. Biochemistry and Molecular Biology Education, 42, 1, pp. 6-14.

Roxa, T, Olsson, T, and Martensson, K (2008) Appropriate Use of Theory in the Scholarship of Teaching and Learning as a Strategy for Institutional Development. Arts and Humanities in Higher Education, 7, 3, pp. 276294.

Shahjahan, R, and Kezar, A (2013) Beyond the 'National Container': addressing methodological nationalism in higher education research. Educational Researcher, 42, 1, pp. 20-29.

Sharma, M, and McShane, K (2008) A Methodological Framework for Understanding and Describing Discipline-based Scholarship of Teaching in Higher Education through Design-based Research. Higher Education Research and Development, 27, 3, pp. 257-270.

Shreeve, A (2011) Joining the Dots: the scholarship of teaching as part of institutional research. Higher Education Research and Development, 30, 1, pp. 63-74.

Simmons, N, and Poole, G (2016) The History of SoTL in Canada: answering calls for action. New Directions for Teaching and Learning, 146, pp. 13-22.

Smith, D, Um, J, and Beversluis, C (2014) The Scholarship of Teaching and Learning in a Christian Context. Christian Higher Education, 13, 1, pp. 74-87.

Tight, M (2012) Researching Higher Education. Maidenhead, Open University Press, second edition.

Tight, M (2013) Discipline and Methodology in Higher Education Research. Higher Education Research and Development, 32, 1, pp. 136-151.

Tight, M (2014a) Discipline and Theory in Higher Education Research. Research Papers in Education, 29, 1, pp. 93-110. 
Tight, M (2014b) Theory Development and Application in Higher Education Research: the case of threshold concepts. pp. 249-267 in J Huisman and M Tight (eds), Theory and Method in Higher Education Research II. Bingley, Emerald.

Tight, M (2014c) Collegiality and Managerialism: a false dichotomy? Evidence from the higher education research literature. Tertiary Education and Management, 20, 4, pp. 294-306.

Tight, M (2014d) Working in Separate Silos? What citation patterns reveal about higher education research internationally. Higher Education, 68, 3, pp. 379-395.

Tight, M (2015a) Theory Development and Application in Higher Education Research: the case of academic drift. Journal of Educational Administration and History, 47, 1, pp. 84-99.

Tight, M (2015b) Theory Development and Application in Higher Education Research: tribes and territories. Higher Education Policy, 28, 4, pp. 277293.

Tight, M (2015c) Theory Development and Application in Higher Education: the case of communities of practice. European Journal of Higher Education, 5, 2, pp. 111-126.

Tight, M (2016a) Phenomenography: the development and application of an innovative research design in higher education research. International Journal of Social Research Methodology, 19, 3, pp. 319-338.

Tight, M (2016b) Examining the Research/Teaching Nexus. European Journal of Higher Education, 6, 4, pp. 293-311.

Tofade, T, Abate, M, and Fu, Y (2014) Perceptions of a Continuing Professional Development Portfolio Model to Enhance the Scholarship of Teaching and Learning. Journal of Pharmacy Practice, 27, 2, pp. 131-137.

Torgerson, C (2003) Systematic Reviews. London, Continuum.

Trepanier, L (2017) SoTL as a Subfield for Political Science Graduate Programs. Journal of Political Science Education, 13, 2, pp. 138-151.

Trigwell, K (2013) Evidence of the Impact of Scholarship of Teaching and Learning Purposes. Teaching and Learning Inquiry, 1, 1, pp. 95-105.

Trigwell, K, Martin, E, Benjamin, J, and Prosser, M (2000) Scholarship of Teaching: a model. Higher Education Research and Development, 19, 2, pp. 155-168.

Trigwell, K, and Shale, S (2004) Student Learning and the Scholarship of University Teaching. Studies in Higher Education, 29, 4, pp. 523-536. 
Vardi, I, and Quin, R (2011) Promotion and the Scholarship of Teaching and Learning. Higher Education Research and Development, 30, 1, pp. 39-49.

Vithal, R (2016) Growing a Scholarship of Teaching and Learning Institutionally. Studies in Higher Education, DOI: 10.1080/03075079.2016.1180350.

Walls. J (2016) A Theoretically Grounded Framework to Integrating the Scholarship of Teaching and Learning. Journal of the Scholarship of Teaching and Learning, 16, 2, pp. 39-55.

Weaver, D, Robbie, D, Kokonis, S, and Miceli, L (2013) Collaborative Scholarship as a Means of improving both University Teaching Practice and Research Capacity. International Journal for Academic Development, 18, 3, pp. 237-250.

Wehbi, S (2009) Reclaiming our Agency in Academia: engaging in the scholarship of teaching in social work. Social Work Education, 28, 5, pp. 502-511.

Willingham-McLain, L (2015) Using a Scholarship of Teaching and Learning Approach to Award Faculty who Innovate. International Journal for Academic Development, 20, 1, pp. 58-75.

Wood, P, and Cajkler, W (2017) Lesson Study: a collaborative approach to scholarship for teaching and learning in higher education. Journal of Further and Higher Education, DOI: 10.1080/0309877X.2016.1261093.

Yair, G (2008) Can we Administer the Scholarship of Teaching? Lessons from outstanding professors in higher education. Higher Education, 55, pp. 447-459. 
Table 1: Articles with 'Scholarship of Teaching' in their title, by date, according to Scopus and Google Scholar

\begin{tabular}{|l|l|l|l|l|}
\hline Date & A & B & C & D \\
\hline 2017 & 12 & 187 & 39 & $\sim 2960$ \\
\hline 2016 & 27 & 335 & 63 & $\sim 4240$ \\
\hline 2015 & 18 & 330 & 64 & $\sim 3700$ \\
\hline 2014 & 29 & 330 & 67 & $\sim 3640$ \\
\hline 2013 & 22 & 297 & 66 & $\sim 3360$ \\
\hline 2012 & 24 & 275 & 72 & $\sim 3010$ \\
\hline 2011 & 21 & 278 & 69 & $\sim 2240$ \\
\hline 2010 & 23 & 293 & 65 & $\sim 2040$ \\
\hline 2009 & 18 & 240 & 63 & $\sim 2060$ \\
\hline 2008 & 31 & 218 & 66 & $\sim 1530$ \\
\hline 2007 & 15 & 169 & 63 & $\sim 1300$ \\
\hline 2006 & 13 & 134 & 38 & $\sim 1030$ \\
\hline 2005 & 17 & 156 & 51 & 778 \\
\hline 2004 & 12 & 121 & 36 & 654 \\
\hline 2003 & 16 & 117 & 37 & 487 \\
\hline 2002 & 15 & 76 & 70 & 532 \\
\hline 2001 & 5 & 74 & 25 & 326 \\
\hline 2000 & 13 & 81 & 18 & 291 \\
\hline $1990-1999$ & 20 & 362 & 39 & 740 \\
\hline Pre-1989 & 18 & 183 & 1 & 93 \\
\hline Total & 369 & 4256 & 914 & 35011 \\
\hline & & & & \\
\hline
\end{tabular}

Notes: search done on $31 / 8 / 17$
A - Scopus, in the title
B - Scopus, in the title, abstract or keywords
C - Google Scholar, in the title
D - Google Scholar, anywhere in the article 